\title{
Exploring Types of Deviant Workplace behavior in a Public Organization in Malaysia.
}

Malini a/p Sathappan

(Department of Professional Development and Continuing Education,

Faculty of Education studies, Universiti Putra Malaysia).

E-mail:malinisathappan@yahoo.com

\section{Dr. Zoharah Omar}

(Department of Professional Development and Continuing Education,

Faculty of Education Studies, Universiti Putra Malaysia, Serdang, Malaysia)

omarzoharah@gmail.com

(Corresponding author)

Prof Aminah Ahmad

(Institute of Social Sciences, Universiti Putra Malaysia, Serdang, Malaysia)

aminahahmad49@gmail.com

(Corresponding author)

Prof Azimi Hamzah

(Department of Professional development and Continuing Education,

Faculty of Education Studies, Universiti Putra Malaysia)

azimihamzah49@gmail.com

(Corresponding author)

Associate Prof Ismi Arif

(Department of Professional Development and Continuing Education,

Faculty of Education Studies,Universiti Putra Malaysia, Serdang, Malaysia)

ismilina@gmail.com

(Corresponding author)

\section{ABSTRACT}

Deviant workplace behavior among employees is becoming a universal issue at various organizations, not excluding enforcement agencies. Deviant behavior need to be studied by scholars to prevent detrimental effects such as job dissatisfaction, intention to quit, stress, decreased productivity, loss of work time, high turnover rate and financial costs among employees. The purpose of this paper is to explore the types of deviant workplace behavior in the government sector in Malaysia. Data collection for the research was carried out by interviewing 14 law enforcement officers in Malaysia. This study involves various departments. The study found that there are various types of misconduct existing at the organization e.g. bribery, uninformed polygamy, drugs, on-line gambling, absenteeism, and lateness. This study also provided a framework on types of misconduct to the enforcement agency.

Keywords: Deviant workplace behavior; Law enforcement agency; Types; Various rank officers; Human resource development.

\section{Academic Discipline}

Sociology

\section{Sub-Disciplines}

Human resource development 


\section{Subject Classification}

Organizational behavior

Type

Interview

\section{Introduction}

The prevalence of workplace deviant behavior Invarious organizations is capturing global attention, due to its high rate of occurrence and negative impact on the organizations. Employees retaliate by exhibiting negative behaviors such as sexual harassment, vandalism, rumor spreading and corporate sabotage (Appelbaum, laconi, \& Matousek, 2007).

The implications of deviant behavior has affected employees psychologically. If employees of an organization are treated with injustice, they will retaliate in various ways such as feelings of anger, outrage, frustration and desire for revenge (Bies \& Tripp, 1996; Greenberg, 1990; Robinson \& Bennett, 1995). Deviance has also been termed as the reaction towards frustrating organizational stressors in the financial, societal and working conditions of an organization (Lawrence \& Robinson, 2007). The impact on social and financial sectors, example the Enron case (Levine, 2005), gave a detailed view on the delinquency of organizational norms, which spread from individuals to teams and became deleterious to organizational performance.

Chirasha and Mahapa (2012) pointed out that $75 \%$ of employees are involved in deviant workplace behavior (DWB), such as theft, fraud, vandalism, sabotage and voluntary absenteeism. Case (2000) found it was their own employees who were engaged in deviant workplace behavior, which caused to a loss of US \$50 to $\$ 200$ billion annually. Oseni (2011) mentioned there were 5 types of unethical behavior that took place in an accounting firm such as monetary gratification, sexual harassment, sales of employment to employees, poor storage of financial records and inadequate employment of qualified accounting staff to handle financial records.

Such deviance can hamper the reputation of an organization and will affect the economy of a country. This is understood to be a growing concern related to deviant workplace behavior (Aquino, Lewis, \& Bradfield, 1999; Colbert, Mount, Harter, Witt, \& Barrick, 2004; Fagbohungbe, Akinbode, \& Ayodeji, 2012). Based on the above consequences researchers need to explore the frequent types that may affect employee behavior and organizational performance. According to Alagaraja and Shuck (2015), Werner and DeSimone (2009), Chirasha and Mahapa (2012), Vardi and Wetize (2004) there are many types of deviant behavior that may influence employee behavior such as property deviance, production deviance, personal aggression and political deviance. There is a need to study types of DWB in the enforcement context because previous researches have applied Robinson and Bennett's (1995) typology to identify the types of deviance in other organizations. However, fewer studies have focused Robinson and Bennett's (1995) typology on an enforcement agency.

\section{Research Objective}

The purpose of the study aims to identify types of workplace deviance and understand the nature of DWB process among various positions of employees in the enforcement agency. The need for such a research has become vital due to the fact that employees are facing work pressure due to organizational changes. This paper will also explore the common types of deviance, which persist at all levels of employees at law enforcement agency.

\section{Literature Review}

Robinson and Bennett (1995, p. 556) defined DWB as "voluntary behavior of organization members, which violates significant organizational norms and in doing so, threatens the well-being of the organization or its members or both".

By using Robinson and Bennett (1995) typology, previous scholars were able to identify types of deviance and relations. It is divided into four quadrants e.g. political deviance, personal aggression, production deviance and property deviance. Furthermore, they also pinpointed two types of workplace deviance such as interpersonal and organizational deviance. They argued that interpersonal deviance as overt and harmful to individuals. Examples of interpersonal deviance such as showing favoritism, gossiping about co-workers, blaming co-workers, competing nonbeneficially, sexual harassment, verbal abuse, stealing from co-workers, endangering co-workers. Additionally Robinson and Bennett (1995) found different types of workplace deviance reflects different consequences.

However, Martin (1996) described it as an act of violence and terror. Examples include answering phone calls with a "yeah", neglecting to say "thank you" or "please", using voicemail to screen calls and standing impatiently over the desk of someone engaged in a phone conversation. Next, Andersson and Pearson (1999) termed it as workplace incivility. It means acting rudely, discourteously or with disregard for others in the workplace in violation of workplace norms of mutual respect. Rioux, Roberge, Brunet, Savoie, and Courcy (2005) also explained it as acts of violence, behavior that may harm an individual's body or property and psychological violence, verbal acts that humiliate an individual. Andersson and Pearson (1999) and Neuman and Baron (1998) pinpointed it is more to verbal rather than physical, passive rather than active, indirect rather than direct and subtle rather than overt. Examples illustrated by Pearson, Andersson, and Porath (2002) include receiving nasty notes, being treated as a child by others at work, being cut off while speaking, being berated for an action committed by another employee, being excluded from a meeting and having one's credibility undermined in public. They grouped it as minor offences. Consequences of the above actions can be nasty, ugly and dangerous. 


\subsection{Types of police deviance}

Police deviance has been defined as police corruption (Ross, 2011; Dean, Bell, \& Lauchs, 2010). Below table shows a typology of police corruption.

Table 1: Roebuck and Barker (1974) Police Corruption Typology.

\begin{tabular}{|c|c|}
\hline Type of Corruption & Examples of behaviors \\
\hline Corruption of Authority & $\begin{array}{l}\text { Seeking or receiving material gain by virtue of position } \\
\text { Without violating the law per se (ex; free meals, merchandise, or } \\
\text { other gratuities not afforded to others outside the position) } \\
\text { (Roebuck \& Barker, 1974) }\end{array}$ \\
\hline Abuse of authority/ Violation of Civil Liberties & $\begin{array}{l}\text { Physical abuse or use of excessive physical force, psychological } \\
\text { abuse through verbal assault or ridicule and legal abuse involving } \\
\text { violation of constitutional or civil rights (Roebuck \& Barker, 1974) }\end{array}$ \\
\hline Kickbacks/Bribes & $\begin{array}{l}\text { Monetary gain for referrals to particular individuals or companies } \\
\text { (such as towing companies, repair shops, lawyers) (Roebuck \& } \\
\text { Barker, 1974) }\end{array}$ \\
\hline Opportunistic Theft & $\begin{array}{l}\text { Theft of property from crime scenes, crime victims, detainees, etc. } \\
\text { (Roebuck \& Barker, 1974) }\end{array}$ \\
\hline Shakedowns & $\begin{array}{l}\text { Solicitations or acceptance of bribes for particular actions (such as } \\
\text { not writing a ticket, not effecting an arrest, not impounding a car) } \\
\text { (Roebuck \& Barker, 1974) }\end{array}$ \\
\hline Protection of Illegal Activities & $\begin{array}{l}\text { Protection from enforcement action for those committing illegal } \\
\text { activities (such as gambling operations, drug dealers, auto thieves) } \\
\text { (Roebuck \& Barker, 1974) }\end{array}$ \\
\hline Fixing arrest or Prosecution & $\begin{array}{l}\text { Intervening in and undermining criminal proceedings, such as } \\
\text { investigation or prosecutions (Roebuck \& Barker, 1974) }\end{array}$ \\
\hline Direct Criminal Activities & $\begin{array}{l}\text { Outright criminal activities by law enforcement officers, in direct } \\
\text { violation of both agency guidelines and legal statutes (Roebuck \& } \\
\text { Barker, 1974) }\end{array}$ \\
\hline Internal Payoffs & $\begin{array}{l}\text { Special prerogatives or benefits available to officers, such as } \\
\text { working holidays for extra pay, overtime shifts, shift allocations, } \\
\text { promotions are bartered or sold (Roebuck \& Barker, 1974) }\end{array}$ \\
\hline Disclosure of Information & $\begin{array}{l}\text { Furnishing confidential information, such as criminal records, the } \\
\text { identities of confidential sources or information concerning ongoing } \\
\text { investigation to those without a legitimate law enforcement interest. }\end{array}$ \\
\hline Discrimination & $\begin{array}{l}\text { Harassment of, taking action against or failing to take proper action } \\
\text { because of an individual's personal characteristics (race, gender, } \\
\text { creed, religion, national origin or sexual orientation). }\end{array}$ \\
\hline Falsification/Lying & $\begin{array}{l}\text { Planting incriminating evidence at crime scenes or on individuals in } \\
\text { order to "strengthen" weak criminal cases or artificially enhance } \\
\text { perceived productivity or falsifying official reports. }\end{array}$ \\
\hline
\end{tabular}

Note: Adapted from Barker (2002), Grant (2002) Punch (2000), Roebuck \& Barker (1974), and Loewenthal (1981).

Based on the above Table 1 police corruption typology by Roebuck and Barker (1974) derived eight types of police corruption. Roebuck and Barker compiled this content analysis base on literature from 1960 to 1972 . However, more research were conducted by other scholars such as Loewenthal (1981), Punch (2000), Barker (2002) and Grant (2002). They included disclosure of information. Discrimination and falsification/lying. From Malaysian perspective, misconduct exists at different stages and it has been explained by Dean et al. (2010) matrix framework. 


\section{Matrix framework of police deviance}

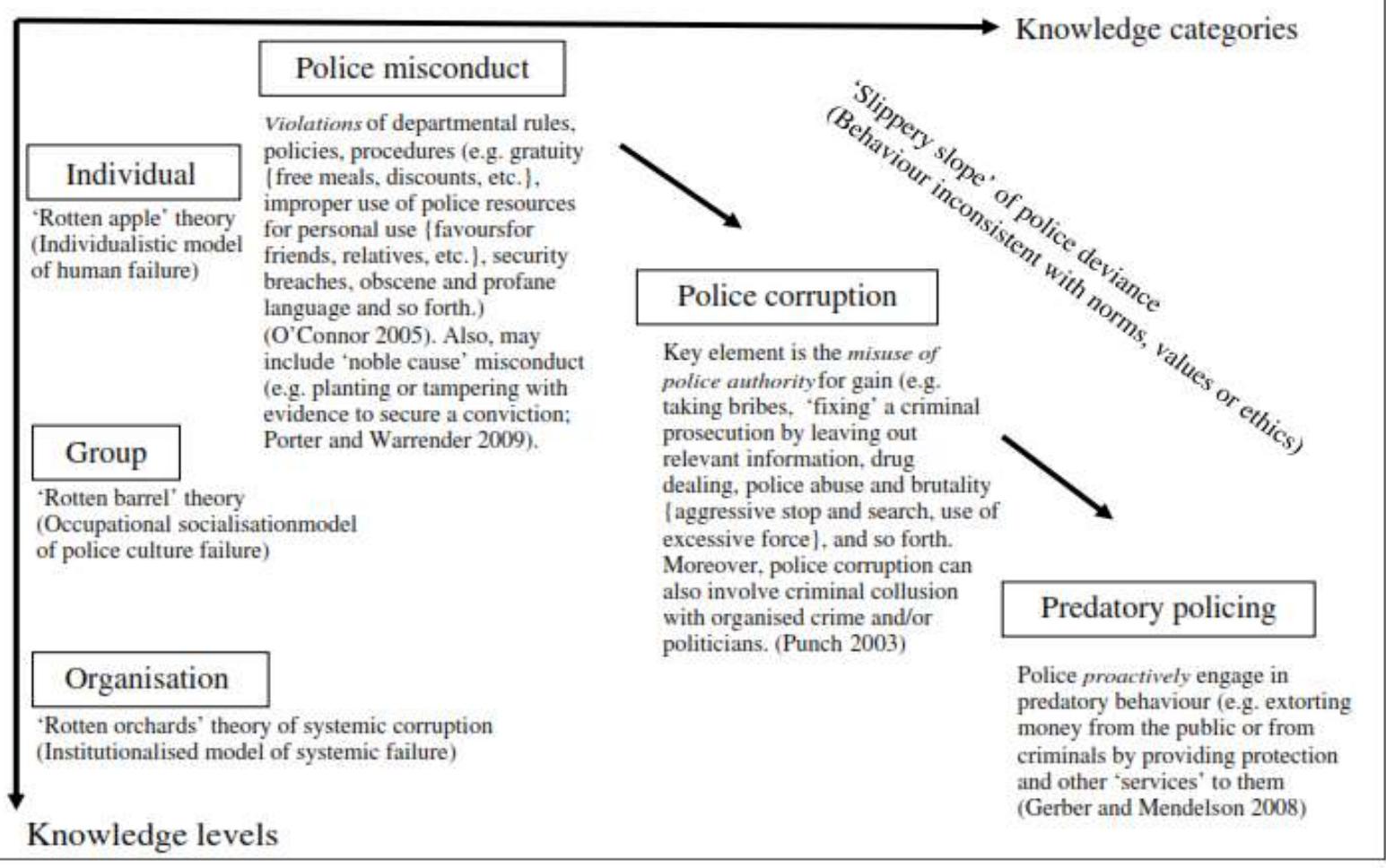

\section{Figure 1: A Two Dimensional Conceptualization of Police Deviance (Dean et al., 2010)}

The most prominent theory of police deviance was developed by O'Connor (2005) by giving a notion called as a Slippery Slope. The author explained that it starts from minor offences to moderate and leads to major offences. This concept suggests that when people begin to deviate they do it in small ways. However, once they have deviated, they begin to slide down a slope that leads to greater and more pronounced types of deviance (Dempsey \& Forst, 2008). Figure 1 presents conceptualization of police deviance.

Hence, Dean et al. (2010) noticed that there was a gap in the literature of police deviance definition thus; he organized a framework, which captured the knowledge about the nature, extent and progression of police deviance from different perspectives at different levels. It created a mosaic of police deviance. Additionally it portrayed more appropriate and important dimensions of police deviance compared to previous scholars.

Dean et al. (2010) has conceptualized police deviance behavior into three types namely police misconduct, police corruption and police predatory. Deviance is classified as any intentional behavior that violates the norms of an organization but police deviance has a sliding scale which ranges from minor to major offences such as accepting gratuity, improper use of police resources for personal use followed by officers taking bribe, drug dealing and end up in extorting money from the public or from criminals by providing protection and other services.

In Figure 1, the top end of the matrix denotes the individual level while at the bottom end shows the organization level. The movement of the individual from top to bottom is mediated through the group. The job of police organization is carried out through group processes in the main and seldom does an individual within organizational context.

The work of the police department is considered as an independent entity. Porter and Warrender (2009) mentioned earlier that police deviance is a problematic issue because there are overlapping categories based on the slippery slope theory. For instance police misconduct like improper use of police resources can often be conceived at the individual level and it can spill over into the category of police corruption when individual officers use such police resources illegally by gaining access to files and intelligence to share with a wider network of corrupt police at the "group level'. Moreover, such corrupt practices involving the improper use of police resources may well extend into predatory policing at an "organizational" or systematic level of institutionalized police deviance. This happens when corrupt police engage in "selling" police intelligence to organized crime groups or even "setting up" other officers to get them removed from sensitive investigations.

\subsection{Method of study}

The study adopted qualitative (case study) approach. It is sought to understand how people a) interpret their experiences, b) construct their worlds and c) discover the meanings they attribute to their experiences (Meriam \& Associates, 2002). 
Researcher would like to explore and understand the types of deviant behavior experienced by respondents of the study. The researcher went with an open mind regarding the subjects to be explored. Fortunately, the interview structure was guided in such a way that it encouraged respondents to have an interesting interaction along with giving examples on their life experiences.

\subsection{Data Collection and Analysis}

A sample of 14 respondents who have experience working in a public enforcement organization were selected for the present study. The respondents were selected through purposive sampling since the researchers intended to get a comprehensive understanding of types of deviant workplace behavior, which was reported.

The researchers selected experienced officers from the law enforcement agency in Malaysia by using purposive sampling. The respondents were full-time employees in various departments with not less than 6 years of work experience. This was a single case study in a law enforcement agency.

Researcher adopted semi-structured interviews for data collection. Dexter (1970) supported interviewing as the best technique to use when conducting intensive case studies for a few individuals. Furthermore, it can give better quality data, more in quantity and is less costly. Besides that, researchers feel comfortable to respond to the situation at hand. Essential questions were directed to the respondents to get the main theme of the study - types of workplace behavior deviance. During interviews, probing questions were used to acquire additional information and to open the doors for further examination of the information obtained from the respondents. In addition, there were also throwaway questions just to build close relationship with the respondents and to make them feel more comfortable, warm and friendly towards the researcher.

The important excerpts from the interviews are given in the following pages.

\subsection{Research Participants}

The researcher conducted in depth face - to - face interviews with the respondents. They were asked essential questions, probing questions and throw away questions. Each interview took between 30 to 60 minutes. All interviews were audio taped and transcribed. The transcribed data were coded and reduced to categories and meaningful themes. The researchers adopted constant comparative model of Glaser and Strauss (1967). This study emphasized the encouragement of participants to express their opinion freely on the subject focused. As has been indicated in table 2 the respondents include 13 males and 1 female. Most of them have long working experience in different departments.

Table 2: Participant Profile

\begin{tabular}{|c|c|c|c|c|}
\hline Respondent & Gender & Position & Experience & Department \\
\hline Respondent 1. & male & $\begin{array}{l}\text { Middle level ranking } \\
\text { officer }\end{array}$ & 36 years & Crime \\
\hline Respondent 2. & female & $\begin{array}{l}\text { Middle level ranking } \\
\text { officer }\end{array}$ & 34 years & Management \\
\hline Respondent 3. & male & $\begin{array}{l}\text { Low level ranking } \\
\text { officer }\end{array}$ & 32 years & General \\
\hline Respondent 4. & male & $\begin{array}{l}\text { Middle level ranking } \\
\text { officer }\end{array}$ & 16 years & Training \\
\hline Respondent 5. & male & $\begin{array}{l}\text { Low level ranking } \\
\text { officer }\end{array}$ & 15 years & $\begin{array}{l}\text { JIPS(Integrity and } \\
\text { standards } \\
\text { compliance } \\
\text { department) }\end{array}$ \\
\hline Respondent 6. & male & $\begin{array}{l}\text { Middle level ranking } \\
\text { officer }\end{array}$ & 14 years & Federal reserve unit \\
\hline Respondent 7. & male & $\begin{array}{l}\text { Middle level ranking } \\
\text { officer }\end{array}$ & 14 years & Crime \\
\hline Respondent 8. & male & $\begin{array}{l}\text { Low level ranking } \\
\text { officer }\end{array}$ & 14 years & $\begin{array}{l}\text { JIPS(Integrity and } \\
\text { standards } \\
\text { compliance } \\
\text { departments) }\end{array}$ \\
\hline Respondent 9. & male & $\begin{array}{l}\text { Middle level ranking } \\
\text { officer }\end{array}$ & 11 years & Investigation \\
\hline Respondent 10. & male & $\begin{array}{l}\text { Low level ranking } \\
\text { officer }\end{array}$ & 11 years & $\begin{array}{l}\text { JIPS(Integrity and } \\
\text { standards } \\
\text { compliance }\end{array}$ \\
\hline
\end{tabular}




\begin{tabular}{|l|l|l|l|l|}
\hline & & & department) \\
\hline Respondent 11. & male & $\begin{array}{l}\text { Middle level ranking } \\
\text { officer }\end{array}$ & 9 years & Crime \\
\hline Respondent 12. & male & $\begin{array}{l}\text { Middle level ranking } \\
\text { officer }\end{array}$ & $\begin{array}{l}\text { Middle level ranking } \\
\text { officer }\end{array}$ & Crime \\
\hline Respondent 13. & male & $\begin{array}{l}\text { Low level ranking } \\
\text { officer }\end{array}$ & General \\
\hline
\end{tabular}

\section{Analysis}

The interviews with the respondents lasted between 30 minutes -60 minutes. All the interviews were audio taped and transcribed. The transcribed data were coded with concurrent comparison of all meanings gained in the process of coding to determine similarities and differences. This method is suggested because its inductive comparative nature provides a systematic method for analyzing any kind of data set. This method enables the researcher to identify themes systematically as they appear from the data (Merriam, 2009). The essential part in this interview was the researchers wanted to explore types of DWB at workplace and encouraged the participants to express their feelings freely on the subject of focus.

\section{Findings and discussion}

The present section presents the results of this exploratory study, arranged in context to the research objective.

What are the types of deviant workplace behavior?

A number of descriptions were provided by the respondents based on officers who witnessed co-workers engaging in one or two types of DWB. All respondents understood DWB as "voluntary behavior of organizational members, which violates significant organizational norms and in doing so, threatens the well-being of the organization or its members or both" (Robinson \& Bennett, 1995, p. 556). There were two themes derived from the interviews (i) police misconduct and (ii) police corruption.

\subsection{Police misconduct}

Police misconduct means police breaking their own internal rules and procedures (Punch, 2000). Informants understood it as violation of departmental rules, policies, and procedures. Findings of the study has identified sub theme of police misconduct as production deviance and personal aggression.

\subsubsection{Unprofessional conduct}

Unprofessional conduct means the misconduct committd by the police has no clear definition or direct material benefit to the officer involved (Prenzler, 2009). Informants of the study understood it as a serious offence, which is reported such as uninformed polygamy, alcohol consumption, drugs, on-line gambling, sleeping on duty.

\subsubsection{Uninformed polygamy}

With reference to Act 303 "Undang-undang Islam" polygamy is a state of marrying more than one wife, a maximum of four wives in Islam is permissible. But it is forbidden by Islamic law if the spouse (male) did not inform his first wife and get consent from her. Two of the respondents mentioned that some officers tend to marry without getting consent from their first wife and approval from the organization. Respondent number 6 illustrated "Policeman marries more than one wife do not want to follow procedures. This often happens. Even low rank officers. They call it as polygamy. There was a case on ex-sergeant working for more than thirty two years was terminated because got married to another woman and no one knows about it because he kept quiet. They try to run away from problem. I have been talking to them why never inform first wife ... but no answer". Besides that respondent 5 officer reported " marrying without approval. Marrying two wives did not inform first wife and the organization, is considered unethical behavior at workplace".

\subsubsection{Alcohol consumption}

Respondent number 9 (inspector) and respondent 11 (ins lor) have experienced subordinates who indulged in alcoho consumption accidently. Respondent 9 narrated that "alcohol is one of the types that I have observed among the officers in the agency. It is wrong to consume alcohol while working... Normally, nightclubs are still open during an operation at $1.00 \mathrm{am}$.Respondent 9 mentioned officers engage in this activity accidently. He also narrated his experience that when there are many offers, the environment..."(encourages bad behavior). On the other hand, respondent 11 also reported it is a serious offence and he had witnessed officers engage in "consumption of alcohol which is primary at his workplace".

\subsubsection{Drugs}

Misuse of drugs is also known as substance abuse. The user consumes the substance in amounts which can harm themselves and others. In most cases, unethical behavior occurs wher person is under the influence of drugs and this will affect their personality in the long term. Respondent 10 (lands cop ffirmed that "Um....this year had 3 to 4 cases. 
Majority of cases were taking drugs". Respondent 5 (lands copral) also quoted "usually those who projects unkemptness of uniform identifies officers who have engaged in drugs". "before entering into the police force they were addicts. It involves both levels of officers (middle and low). They will stop from taking drugs once they are selected as police officers for training. Once they have completed training they are free to involve in drugs addiction. Taking drugs is something normal...". Therefore it is understood some of the officers were addicts before joining the agency.

\subsubsection{On-line gambling}

On-line gambling is the wagering of money or something of material value an event with an uncertain outcome conducted with the primary intent of winning additional money or material goods through on-line system. Respondent 5 has witnessed and affirmed " at present I can see ....spending more than salary received, on-line gambling. Now we are trying to combat this type of deviant behavior". He described it as "it is hidden behind a dark glass. When people are involved in on-line gambling makes a person loose his pay". Respondent 10 agreed with the above q He indicated that "on-line gambling is undeniable, it is the latest. It is mentioned in code of conduct (PTKPN) tha officers or employees are prohibited from visiting the entertainment centers and gambling centers without reasonable cause or excuse".

\subsubsection{Sleeping on duty}

Sleeping on duty is a rule violation based on PPP(A) 2002 code of conduct. With reference to section 4(2) (j) it states any individual who is negligent in performing his or her duties is classified as deviant behavior. To explain this type of deviance respondent 3 has described as "sleeping on duty is usual. Normally shift from 12 midnight to 8 morning cannot deny. Accidently they are sleeping. They sleep without being aware that officers are being monitored during night. Some officers need to be knocked to make them awake. Maybe tired do not know what to do, sitting for long can make a person tired. Officers who assigned to work during shift usually shows a sign of exhausted because they have to work from 11 in the night to 7 in the morning next day. Then at 4 in the afternoon on the same day they have to follow duty roster". Respondent 14 further elaborated that officers sleeping on duty is an accident and not a deliberate action. He narrated, "I sign in at 12 midnight and sign out 8 morning next day. Then at 4 afternoon I will continue work according to duty roster. I only have 3 hours of sleep at home. That is the reason why I tend to sleep on duty. I don't have any intention of falling asleep during guarding the lockup. Sleeping on duty is a type of misconduct. If this is noted by senior officers then he or she will be taken disciplinary action. Sleeping on duty is an offence".

\subsubsection{Interpersonal misbehavior}

Interpersonal misbehavior means behaviors which are performed towards colleagues or managers (eg incivility, harassment, insults). It is to hurt others or the organizations (Vardi \& Weitz, 2004). Participants of the study understood intrapersonal misbehavior as minor offence, no evidence and creates humor. Findings of the study identified intrapersonal misbehavior as sexual harassment and verbal abuse.

\subsubsection{Sexual harassment}

The respondents explained sexual harassment behavior as watching pornography, verbal and non-verbal acts. It occurs between an officer in power towards a subordinate. The data indicated that this happens in every department but it is not highlighted because there is no evidence and is considered as humor at workplace. According to respondent 4 , who stated that "I'd say it exists in all departments but not highlighted because there is no evidence. Examples of sexual harassment are like watching pictures in the internet. Sexual harassment usually between officers and subordinates but action is seldom taken because there is no report and considered as humor".

Generally, respondent 8 who is a sergeant agreed that it happens in most places (organizations). "Sexual harassment exists in all places" he said. "Officers should not voice about porno words....non- verbal communication such as body language gesture and obscene signs exists". The evidence proved that the respondents made it clear that sexual harassment took place at their settings, but it was not reported due to it being a minor offence. The harassers and victims took it as an embarrassing act if the incident was reported. Therefore, it is not reported in order to safe guard their reputation as well as that of the organization.

\subsubsection{Verbal abuse}

Respondent 1, 2 and 7 have experienced officers using abusive words during working hours and felt offended. They also felt it is unavoidable because such situations are created due to job scope and duties. It sometimes affects communication or getting to know a person. They use offensive language to humiliate and gain power over another person. Respondent 1 affirmed "verbal abuse at the enquiry counter between the public and officer in charge". Respondent 1 explained, the situation occurs due to the officer in-charge receiving too many complaints from the public and in he or she being stressed. Similarly respondent 7 agreed with this situation because he has also witnessed the same acts at workplace. Respondent 7 narrated "verbal abuse occurs but it can be controlled. Normally two officers are on duty 24 hours. An officer receives 20 to 30 reports. This is tiring which triggers anger..... an unstable human behavior". However, verbal abuse does occur between the subordinates and supervisor. Respondent 2 quoted that "at times meetings leaders use vulgar words.... At times meetings, which have to be listened (subordinates). Difficult to change mindset (leader). Stubborn take the words positively".

The above incidents pointed out that verbal abuse is between a higher ranking officer and his or her subordinates and also with the public. Verbal abuse occurs because of the frustration and anger at workplace. Words are used to attack and control over people. 


\subsection{Police Corruption}

Police corruption has been defined as the misuse of police authority for gain e.g taking bribes, fixing a criminal prosecution by leaving out relevant information, drug dealing (Punch, 2003).Besides that Roebuck and Barker (1974) classified corruption as (a) abuse of authority, (b) kickbacks/bribes, (c) opportunities theft, (d) shakedowns, (e) protection of illegal activities, (f) fixing arrest or prosecution, (g) direct criminal activities, (h) internal payoffs, (i) disclosure of information, (j) discrimination and (I) falsification/lying. Informants of the study identified police corruption as bribery. They described bribery is an act unrelated to official duties. Examples obtaining money, gifts, positions, loans, wages, services or bonus.

\subsubsection{Bribery}

Bribery has been described by respondent 9 as "an act unrelated to his official duties. Examples of corruption are in terms of money, gifts, position, loan, wages, services or bonus in which enforcement officers uses his discretion to obtain the above mentioned items". Similarly respondent no 2, 1, 12 and 8 agreed that bribery exists and cannot be denied. Respondent no 2 mentioned that "due to promotion the case was closed but the officer was granted the promotion because that particular officer bribed to get her promotion. Furthermore, she explained that it was a win-win situation for both parties" Respondent number 1 explained that bribery exists in many forms ... a treat to lunch or dinner... means there are discreet, crooked activities between the payer and receiver". In another case, respondent no 7 affirmed, "I have observed the following accepting bribes for investigation papers that should be completed. There are bribes, if there is an offer the investigation will be done and if not, it will be delayed ... unfairness towards certain cases". Similarly respondent number 14 (constable) said, "misuse of power example police have power to detain, investigate and arrest for 24 hours. But there are officers who misuse their power to get money during work". Generally respondent number 12 (middle level officer) said, "it is impossible to eradicate bribery".

Lastly the data reveals that bribery persists and it can be minimized but cannot be demolished in this organization. However, some of the respondents hesitate to further explain this case but there are a few respondents who discussed openly.

\subsubsection{Stealing}

Based on Roebuck and Barker (1974) typology stealing is defined as opportunistic theft. It is a theft of property from crime scenes, crime victims and detainees. Respondent 9 affirmed stealing as an offence If they ( senior officers)do not give the right instructions and the law cannot blame the officer in the settings because he or she follows senior officers instructions. He explained that "example raiding inspection of houses, for valuable items, the officer did not instruct (his subordinates) to record valuable items. Later the victims reported valuable items such as gadgets missing. In other words, this is not a trustworthy act and not transparent". "This has happened even though it is a small matter but it can affect image of the police organization".

Another experience shared by respondent 6 , who said "during raid cases officers tend to take things or properties which do not belong to them. He sees stealing or theft on duty occurs if officers are given an opportunity. Without much hesitation and thinking about the consequences, they grab other people's belongings. Therefore, during raid cases respondents 9 and 6 blame the leader and the opportunity available for officers to indulge in deviant behavior.

\subsubsection{Document leakage}

Document leakage can be defined as disclosure of information. It includes the furnishing of confidential information, such as criminal records, the identities of confidential sources or information concerning ongoing investigation to those without a legitimate law enforcement interest (Roebuck \& Barker, 1974). Document leakage has been identified by respondent number 7 as violating official secrets acts through communication. Based on law enforcement code of conduct (PPP (A) 2002) certain information is kept as confidential matter. Such information should not be circulated among their co-workers in the same organization. Unfortunately, sometimes officers break these norms. Respondent number 7 narrated " pictures on face book that should not be exposed to the public. This means leakage of information or official secrets to me is unethical. Information regarding investigation, pictures are not supposed to be exposed to the public. We have to circulate among ourselves". "If confidential issues spreads via communication mode can disturb the investigation process".

\section{Discussion}

It is proven from the above explanations that respondents from all level of positions do report and have witnessed one or more types of deviant behavior. They perceive deviant workplace behavior as rule violation based on PPP (A) 2002 guidelines. Therefore, these respondents are aware of the negative behavior of their co-workers.

The findings of the research question relating to this study is to add to the understanding of the new types of workplace deviant behavior among various rank officers. Findings confirmed that it supported Dean's matrix framework (2010) which have categorized into two types police misconduct and police corruption.

Next police misconduct has been categorized into two types (i) unprofessional conduct and (ii) interpersonal misbehavior. Unprofessional conduct is individually directed and harming the individual itself. Thus it adds to new conceptualization of police misconduct which was introduced by Dean's matrix framework. Whereas interpersonal misbehavior is similar with interpersonally directed by and categorized as serious offence (Robinson \& Bennett, 1995). Informants identified 
interpersonal misbehavior as minor offence because informants perceive it as humor and lack of evidence in reporting those cases.

Findings discovered five types of unprofessional conduct such as uninformed polygamy, alcohol consumption, drugs, online gambling, and sleeping on duty. It was proven that uninformed polygamy, on-line gambling and sleeping on duty were new types of unprofessional conduct which was not mentioned by previous Robinson and Bennett's (1995) typology or Dean's (2010) matrix framework.

Secondly, informants of the study regard bribery, stealing and documents leakage as police corruption. They assume it as unrelated to official duties. Therefore, there is similarity in understanding bribery as a moderate offence by the informants with Dean et al. (2010) matrix framework. Whereas Roebuck and Barker (1974) have defined bribery as accepting monetary gain for referrals to particular individuals or companies. Similarly, informants perceived it actions involving obtaining money from public, gifts from public, position, loans, wages, services or bonus. Which is similar to Roebuck and Barker's (1974) definition. However, findings discovered bribery can be in a non-monetary value such as position and services. Position and services here refers to authority of an officer to get something done to please others.

However, Weber and Getz (2004) explained bribe as "transaction involving two people, the payer and receiver". Either actor can be a member of the public or the private sector. If the payer initiates the transaction, it is a bribe if the receiver demands a payment it is extortion. Therefore, findings of this study indicate bribery occurs among the officers while dealing with the public. Payer here refers to public who initiates the transaction.

Lastly stealing and document leakage is classified as corruption similar with Roebuck and barker's (1974) typology. Hence Dean's matrix framework did not specifically mention stealing and document leakage as police corruption.

\section{Conclusion}

From the findings of the study it is confirmed that identifying the types of deviant workplace behavior is essential to minimize the negative behaviors exhibited in employees of an organization. Deviance at workplace persists at different levels of rank officers. This is due to generation gap. Senior officers blamed junior officers for rule violation. Contrastingly junior officers blame senior officer for accepting bribe and rule violation. Therefore, findings showed types of deviance has been experienced by different departments, locations and ranking officers. Understanding the types of DWB enables current employees of an organization to be aware of the frequent types of deviance, which has been reported at a workplace. It is to be noted that police misconduct and police corruption can affect officers morale, commitment and productivity towards building a healthy work environment.

\section{Limitations}

Practical purposes of this study is pertinent to law enforcement officers. However, this study cannot be generalized to other enforcement agencies.

\section{REFERENCES}

[1] Alagaraja, M., \& Shuck, B. (2015). Exploring organizational alignment-employee engagement linkages and impact on individual performance: A conceptual model. Human Resource Development Review, 14(1), 17-37.

[2] Andersson, L. M., \& Pearson, C. M. (1999). Tit for tat? The spiraling effect of incivility in the workplace. Academy of Management Review, 24(3), 452-471.

[3] Appelbaum, S. H., laconi, G. D., \& Matousek, A. (2007). Positive and negative deviant workplace behaviors: Causes impacts, and solutions. Corporate Governance: The International Journal of Business in Society, 7(5), 586-598.

[4] Aquino, K., Lewis, M. U., \& Bradfield, M. (1999). Justice constructs, negative affectivity, and employee deviance: A proposed model and empirical test. Journal of Organizational Behavior, 20(7), 1073-1091.

[5] Barker, T. (2002). Ethical police behavior. Policing and misconduct. Upper Saddle River, NJ: Prentice Hall.

[6] Bies, R. J., \& Tripp, T. M. (1996). Beyond distrust: "Getting even" and the need for revenge. In R. M. Kramer, \& T. R. Tyler, Trust in organizations: Frontiers of theory and research (pp. 246-260). Thousand Oaks, CA, US: Sage Publications, Inc.

[7] Case, J. (2000). Employee theft: The profit killer. Del Mar, CA: John Case \& Associates.

[8] Chirasha, V., \& Mahapa, M. (2012). An analysis of the causes and impact of deviant behavior in the workplace. The case of secretaries in State Universities. Journal of Emerging Trends in Economics and Management Sciences, 3(5), 415-421.

[9] Colbert, A. E., Mount, M. K., Harter, J. K., Witt, L. A., \& Barrick, M. R. (2004). Interactive effects of personality and perceptions of the work situation on workplace deviance. Journal of Applied Psychology, 89(4), 599-609. doi:http://dx.doi.org/10.1037/0021-9010.89.4.599

[10] Dean, G., Bell, P., \& Lauchs, M. (2010). Conceptual framework for managing knowledge of police deviance. Policing \& Society, 20(2), 204-222.

[11] Dempsey, J. S., \& Forst, L. S. (2008). An Introduction to Policing. Belmont, CA: Wadsworth. 
12] Dexter, L. A. (1970). Elite and specialized interviewing. Evanston: Northwestern University Press.

[13] Fagbohungbe, B. O., Akinbode, G. A., \& Ayodeji, F. (2012). Organizational determinants of workplace deviant behaviours: An empirical analysis in Nigeria. International Journal of Business and Management, 7(5), $207-221$.

[14] Glaser, B., \& Strauss, A. (1967). The Discovery Grounded Theory: Strategies for Qualitative Inquiry. Chicago: Aldin.

[15] Grant, J. K. (2002). Ethics and Law Enforcement, FBI Law Enforcement Bulletin.

[16] Greenberg, J. (1990). Employee theft as a reaction to underpayment inequity: The hidden cost of pay cuts. Journal of Applied Psychology, 75(5), 561-568.

[17] Lawrence, T. B., \& Robinson, S. L. (2007). Ain't misbehavin: Workplace deviance as organizational resistance. Journal of Management, 33(3), 378-394.

[18] Levine, D. P. (2005). The corrupt organization. Human Relations, 58(6), 723 - 740.

[19] Loewenthal, M. A. (1981). Police professionalism-law and ethics. Journal of Contemporary Criminal Justice, 2(1), 1013.

[20] Martin, T. C. (1996). Comprehensive Terrorism Prevention Act of 1995. Seton Hall Legis. J.

[21] Merriam, S. B. (2009). Qualitative research: A guide to design and implementation: Revised and expanded from qualitative research and case study applications in education. San Franscisco: Jossey-Bass.

[22] Merriam, S. B., \& Associates. (2002). Sharan B. Merriam and Associates: Qualitative Research in Practice. Examples for Dis-cussion and. San Francisco, CA: Jossey-Bass.

[23] Neuman, J. H., \& Baron, R. A. (1998). Workplace violence and workplace aggression: Evidence concerning specific forms, potential causes, and preferred targets. Journal of Management, 24(3), 391-419.

[24] O'Connor, T. R. (2005). Police deviance and ethics. Part of web cited, MegaLinks in Criminal Justice. Retrieved from http://www. faculty. ncwc. edu/toconnor/205/205lect11. htm

[25] Oseni, A. (2011). Unethical behavior by professional accountant in an organization. Research Journal of Finance and Accounting, 2(2), 1-8.

[26] Pearson, C. M., Andersson, L. M., \& Porath, C. L. (2002). Assessing and attacking workplace incivility. Organizational Dynamics, 29(2), 123-137.

[27] Porter, L. E., \& Warrender, , C. (2009). A multivariate model of police deviance: examining the nature of corruption, crime and misconduct. Policing \& Society, 19(1), 79-99.

[28] Punch, M. (2000). Police corruption and its prevention. European Journal on Criminal Policy and Research, 8(3), 301324.

[29] Rioux, P., Roberge, M. E., Brunet, L., Savoie, A., \& Courcy, F. (2005). Classification des comportements antisociaux au travail: établissement d'une nouvelle classification. Interactions, 9(1), 63-88.

[30] Robinson, S. L., \& Bennett, R. (1995). A typology of deviance workplace behavior: A multidimensional scaling study. Academy of Management Journal, 38(2), 555-572.

[31] Roebuck, J. B., \& Barker, T. (1974). A typology of police corruption. Social Problems, 21(3), 423-437.

[32] Ross, J. I. (2011). Cutting the Edge: Current Perspectives in Radical/Critical Criminology and Criminal Justice. Transaction Publishers.

[33] Vardi, Y., \& Wetize, E. (2004). Misbehavior in organization theory, research and management. USA: Lawrence Erlbaum Associates Publishers.

[34] Weber, J., \& Getz, K. (2004). Buy bribes or bye-bye bribes: The future status of bribery in international commerce. Business Ethics Quarterly, 14(4), 695-711.

[35] Werner, J. M., \& DeSimone, R. L. (2009). Human Resource Development (5th ed ed.). South-Western, USA: Cengage Learning.

\section{Biography}

Malini Sathappan was born in Pontian, Johor. She obtained her Bachelor degree in Human Science Development (major in consumer studies) from Universiti Putra Malaysia in 1999. She earned her Master's degree in human resource development from Universiti Putra Malaysia in 2010. She worked as a human resource executive in training department in a private university in Malaysia. Then she joined as a lecturer, teaching human resource subjects for undergraduates. Her research interests are human resource development, workplace deviant behavior and organizational behavior. 